\author{
Agnieszka Żołądkiewicz-Kuzioła \\ Nicolaus Copernicus University \\ e-mail: a_zoladkiewicz@umk.pl \\ ORCID: 0000-0001-5475-4826
}

\title{
TAX INSTRUMENTS TO SUPPORT ENTERPRISES \\ IN THE SME SECTOR USING THE EXAMPLE \\ OF THE COMMUNES OF LUBLIN \\ AND MAZOVIA PROVINCES
}

PODATKOWE INSTRUMENTY WSPIERANIA

PRZEDSIĘBIORSTW SEKTORA MŚP

NA PRZYKLADZIE GMIN WOJEWÓDZTWA

LUBELSKIEGO I MAZOWIECKIEGO

DOI: $10.15611 /$ pn.2019.9.10

JEL Classification: H71, L26

Summary: The purpose of the paper is to assess the use of tax instruments by communes of the Lublin and Mazowia provinces as instruments to support enterprises in the SME sector, as well as the presentation of the opinions of micro, small and medium enterprises on the given instruments. For the purposes of the work, a description of tax instruments was made in terms of supporting enterprises. The article uses studies of the literature and the analysis of legal acts. The paper is based on the results of the author's two studies, i.e. a survey conducted among all the communes in Poland and a focused group interview with representatives of private enterprises in the SME sector As a result of the research, it was found that communes largely use tax instruments to support enterprises. On the other hand, enterprises from the SME sector are willing to use these instruments owing to the improvement of their enterprise's financial standing.

Keywords: commune, SME sector enterprises, tax instruments, support for enterprises, local taxes and fees.

Streszczenie: Celem pracy jest ocena stosowania przez gminy województwa lubelskiego i mazowieckiego instrumentów podatkowych jako instrumentów wspierania przedsiębiorstw sektora MŚP, a także prezentacja opinii mikro-, małych i średnich przedsiębiorstw na temat danych instrumentów. Na potrzeby pracy została dokonana charakterystyka instrumentów podatkowych pod kątem wspierania przedsiębiorstw. W artykule wykorzystano studia literatury oraz analizę aktów prawnych. Praca oparta jest na wynikach dwóch badań własnych, tzn. na badaniu ankietowym przeprowadzonym wśród wszystkich gmin w Polsce oraz na zogniskowanym wywiadzie grupowym z udziałem przedstawicieli prywatnych przedsię- 
biorstw sektora MŚP. W rezultacie przeprowadzonych badań zostało stwierdzone, że gminy w znacznym stopniu stosują instrumenty podatkowe w ramach wspierania przedsiębiorstw. Natomiast przedsiębiorstwa sektora MŚP wyrażają chęć korzystania z tych instrumentów ze względu na poprawę sytuacji finansowej swojego przedsiębiorstwa.

Słowa kluczowe: gmina, przedsiębiorstwa sektora MŚP, instrumenty podatkowe, wspieranie przedsiębiorstw, podatki i opłaty lokalne.

\section{Introduction}

The specific role of micro, small, and medium enterprises ${ }^{1}$ (enterprises of the SME sector) in the economy of the country is emphasized in the literature of the subject as well as in practice. In its 2007 communication on the role of micro, small, and mediumsized enterprises, the European Commission emphasizes the essence of these enterprises by calling them the core of the economy [Mate $i$ średnie... 2007, p. 3). The most important aspects related to the business activity of the SME sector include, above all, the significant impact on the local labour market, ${ }^{2}$ and also on the level of the wealth of residents, the significant share in the creation of GDP, ${ }^{3}$ the creation of entrepreneurial attitudes, development of education, culture, sport, and other areas of social life [Kamińska 2011, pp. 7, 75; Lachiewicz 2012, p. 37]. Due to the very important role that entities of the SME sector play in the economy of the country, it is important to support them.

As part of supporting SME sector enterprises, local government units, in particular communes, deserve special attention. It is they that are the first public partner for entrepreneurs operating in their area.

Commune authorities have at their disposal numerous forms of supporting enterprises, however, as the literature on the subject indicates, in practice they rely mainly on budgetary instruments [Denek, Rolewicz 1998; Krajewski, Śliwa 2004; Słomińska 2007; Kogut-Jaworska 2008; Lisowska 2010] as part of which income and expenditure instruments are listed. Income instruments include, in particular, fiscal policy instruments, instruments related to the sale or release for use of property components, price policy instruments, as well as instruments related to the economic development and use of the natural environment. The instruments of fiscal policy

${ }^{1}$ According to the definition expressed in the Act of March 6, 2018 - the Entrepreneurs Law, a micro-entrepreneur is an entrepreneur who employs an average of up to 9 employees on an annual basis and achieves an annual turnover not exceeding the equivalent of EUR 2 million. A small entrepreneur is an entrepreneur who employs an average of 10 to 49 employees on an annual basis and achieves an annual turnover not exceeding the equivalent of EUR 10 million. A medium-sized entrepreneur is an entrepreneur who employs an average of 50 to 249 employees on an annual basis and achieves an annual turnover not exceeding the equivalent of EUR 50 million [Ustawa $\mathrm{z}$ dnia 6 marca $2018 \mathrm{r}$.].

${ }^{2}$ In 2017, 2.08 million enterprises operated in Poland, of which enterprises in the SME sector constituted $99.8 \%$. Over 6.7 million people worked in a given sector in 2017 , which constituted $68.3 \%$ of the total number of employees in the enterprise sector [Raport o stanie... 2019, pp. 15-16, 27].

3 The share of enterprises in GDP production in 2016 was estimated at $73.6 \%$, while the share of enterprises in the SME sector was at the level of 49.8\% [Raport o stanie... 2019, p. 23]. 
include, first of all, the possibility of using, only by the commune's local authority, preferences as part of taxes and local fees [Wójtowicz 2013, pp. 413-414].

The purpose of the paper is to assess the use of tax instruments by communes of the Lublin and Mazovia provinces to support enterprises in the SME sector, as well as the presentation of opinions of micro, small and medium enterprises on the given instruments. The article uses studies of the literature and the analysis of legal acts. The paper is based on the results of the author's two studies, i.e. a survey conducted among all the communes in Poland and a focused group interview with representatives of private enterprises in the SME sector.

\section{Tax authority of communes and tax instruments supporting enterprises}

"A tax is a public law, free of charge, compulsory, and non-returnable cash performance for the benefit of the State Treasury, province, poviat, or commune resulting from the tax act" [Ustawa $\mathrm{z}$ dnia 29 sierpnia $1997 \mathrm{r}$.]. The basic function of taxes is the fiscal function, expressed in the accumulation of public revenues for the implementation of various tasks. Taxes also perform a regulatory function consisting primarily in forming the income and property of taxpayers, and a stimulus function under which, in order to exert specific influence on the decisions of entities, the tax burden which various entities are subjected to is varied [Wołowiec 2019, p. 25].

The scope of tax authority granted to commune bodies, which makes it possible for them to take specific decisions in tax matters [Wójtowicz 2013, p. 414], is of particular importance in terms of using tax instruments by the commune. The tax instruments used by the commune local authority as part of their support for enterprises are based primarily on such elements concerning the structure of taxes as tax rates, tax breaks, and exemptions [Rolewicz 1996, p. 16].

Tax rates are amounts of tax expressed as a percentage or amount, which are collected on the tax base [Kogut-Jaworska 2008, p. 95]. They are set annually by the Minister of Finance in the executive regulation to the Act on local taxes and fees. Taking care of the interests of taxpayers, the commune council, by virtue of its tax authority, may by resolution set lower rates than those set by the Minister of Finance [Rolewicz 1996, p. 16]. It is worth noting, however, that the rates cannot be reduced to zero because such a situation would already bear the nature of a tax exemption, and the commune council does not have such competence [Skica, Kiebała, Wołowiec 2011, p. 122].

An expression of the commune's tax authority in terms of supporting enterprises is also the possibility of introducing other than statutory breaks and exemptions. ${ }^{4}$ Examples of exemptions used in specific communes to support enterprises are presented in Table 1.

${ }^{4}$ Tax breaks are partial exemptions in the form of deductions from the tax base and in the form of deductions from the amount of tax. Tax exemptions are total waivers of tax collection which may be granted to a specific entity or may cover an entity [Kogut-Jaworska 2008, p. 95]. 
Table 1. Examples of tax exemptions used by a commune to enterprises

\begin{tabular}{|c|c|c|}
\hline Commune & Description of tax exemption & Tax exemption period \\
\hline $\begin{array}{l}\text { Bochnia } \\
\text { commune }\end{array}$ & $\begin{array}{l}\text { Exemption from the property tax } \\
\text { on land, buildings, and structures } \\
\text { or their parts used for business by } \\
\text { entities undertaking business activity } \\
\text { in Bochnia Commune for the first } \\
\text { time on the basis of an entry in the } \\
\text { register of entrepreneurs or business } \\
\text { activity records kept in the form of } \\
\text { the National Court Register or CEiDG } \\
\text { [Central Registration and Information } \\
\text { on Business]. }\end{array}$ & $\begin{array}{l}1 \text { year beginning from the month following the } \\
\text { month in which the entity conducting business } \\
\text { activity notified its intention to use the aid de } \\
\text { minimis. }\end{array}$ \\
\hline $\begin{array}{l}\text { Rawicz } \\
\text { commune }\end{array}$ & $\begin{array}{l}\text { Exemption from the property tax on } \\
\text { undeveloped land being the property of } \\
\text { the entrepreneur, related to conducting } \\
\text { business activity, on which the taxpayer } \\
\text { will commence the implementation of a } \\
\text { new investment. }\end{array}$ & $\begin{array}{l}\text { The exemption period is counted from the } 1^{\text {st }} \\
\text { day of the month following the month in which } \\
\text { the implementation of the new investment was } \\
\text { commenced and amounts to a maximum of } 24 \\
\text { months, but not longer than to the end of the } \\
\text { month in which the investment was completed. }\end{array}$ \\
\hline $\begin{array}{l}\text { Września } \\
\text { commune }\end{array}$ & $\begin{array}{l}\text { Exemption from the property tax on } \\
\text { the buildings or their parts, related to } \\
\text { the conducting of production or service } \\
\text { business activity, as a result of which } \\
\text { new jobs related to the new investment } \\
\text { will be created. }\end{array}$ & $\begin{array}{l}\text { Exemption is granted for the period of: } \\
\text { - } 1 \text { year, if at least } 10 \text { jobs have been created } \\
\text { as a result of the new investment, } \\
\text { - } 2 \text { years, if at least } 30 \text { jobs have been created } \\
\text { as a result of the new investment, } \\
\text { - } 3 \text { years, if at least } 100 \text { jobs have been cre- } \\
\text { ated as a result of the new investment, } \\
\text { - } 4 \text { years, if at least } 200 \text { jobs have been cre- } \\
\text { ated as a result of the new investment, } \\
\text { - } 5 \text { years, if at least } 300 \text { jobs have been cre- } \\
\text { ated as a result of the new investment }\end{array}$ \\
\hline $\begin{array}{l}\text { Gierałtowice } \\
\text { commune }\end{array}$ & $\begin{array}{l}\text { Exemption from the property tax on the } \\
\text { buildings, or their parts, and structures } \\
\text { or their parts, arising as a result of } \\
\text { the implementation of an initial } \\
\text { investment, related to the conducting } \\
\text { of business activity by entrepreneurs, } \\
\text { as well as on the buildings, or their } \\
\text { parts, and structures, or their parts, } \\
\text { acquired as the initial investment, } \\
\text { related to the conducting of business } \\
\text { activity by entrepreneurs, belonging to } \\
\text { a plant which has been closed down or } \\
\text { would have been closed down, had it } \\
\text { not been for the acquisition. }\end{array}$ & $\begin{array}{l}\text { The exemption is granted until the end of } \\
\text { the month preceding the month in which the } \\
\text { maximum intensities or the maximum value } \\
\text { of the aid were exceeded, not longer than for } \\
\text { a period of } 4 \text { years from the date of completion } \\
\text { of the investment, and for small and medium } \\
\text { enterprises for a period not longer than } 3 \text { years } \\
\text { from the day of completion of the investment. }\end{array}$ \\
\hline
\end{tabular}

Source: own study on the basis of: [Uchwała nr XIII/125/15 Rady Gminy Bochnia z dnia 30 grudnia 2015 r.; Uchwała nr XXXV/368/17 Rady Miejskiej Gminy Rawicz z dnia 14 lutego 2017 r.; Uchwała nr XXXIV/404/2014 Rady Miejskiej we Wrześni z dnia 16 września 2014 r.; Uchwała nr XXVII/172/16 Rady Gminy Gierałtowice z dnia 8 listopada 2016 r.]. 
In addition, the executive bodies of communes ('wójt' [commune head], mayor, or city mayor) may, at the taxpayer's request, apply instruments supporting enterprises in the form of the so-called breaks in the payment of tax liabilities, which according to the Tax Code include [Ustawa z dnia 29 sierpnia $1997 \mathrm{r}$.]:

- deferment of tax payment and the payment of tax arrears

- spreading the payment tax and tax arrears over instalments,

- remission of tax arrears, default interest, and extension fees in whole or in part.

The premise for the granting of the above breaks in the payment of tax liabilities may be in the taxpayer's important interest, or in the public interest. The taxpayer's important interest is a situation when, "because of extraordinary events, or acts of God, the taxpayer is unable to settle tax arrears." In turn, an important public interest is a situation when "the payment of tax arrears makes the taxpayer resort to state aid measures because he or she will not be able to satisfy his or her material needs" [Cilak 2013, p. 125].

Commune decisions related to the use of tax instruments to support enterprises are not easy. On the one hand, easing tax burdens can have a positive impact on enterprises, but, on the other hand, it reduces the budget revenues necessary for the implementation of the commune's local authority tasks. However, it is worth noting that the use of given instruments may in the future increase the number of entities subject to tax liability and, thus, result in an increase in budget revenues [Rolewicz 1996, p. 16].

\section{Results of research}

For the purposes of implementing the goal assumed in the paper, the results of two original studies were used. The first study, a survey, was conducted in the period from September 2018 to December 2018. The research tool used was an electronic questionnaire that was sent directly to the e-mail addresses of all the communes in Poland (2478 communes). The article presents selected results of the study carried out only for the communes of the Lublin and Mazovia provinces. Province data were selected on account of the additional comparison of the answers of communes in the provinces with the lowest and the highest values of the synthetic entrepreneurship index. ${ }^{5}$ In the Lublin province, the questionnaire was sent back by 68 out of 213 communes, while in the Mazovia province, by 88 out of 314 communes. It is worth noting, however, that not all the returned questionnaires were completed in full,

${ }^{5}$ The value of the synthetic entrepreneurship index for the Mazovia province in 2017 was 83.7, and for the Lublin province 21.4. The synthetic index (SI) was prepared according to the formula: SI $=(p \times n x) \times 100 / \max (p \times n x)$ where: $n-$ number of variables, $x$ - number of points for the variables that are the sum of places occupied by the region in the ranking in individual subrankings, $p$ - number of places in the ranking, $\max (p \times n x)$ - maximum number of points that can be obtained in the event of taking first place in all subrankings. The value of the index is the level of the region achieving the maximum result, i.e. taking first place in all subrankings [Raport o stanie... 2019, p. 44]. 
which is why the results presented contain percentage values indicating no answer to the indicated question.

The other study ${ }^{6}$ was commissioned by the author from the IPC Research Institute. It involved conducting a focused group interview $\left(\mathrm{FGI}^{7}\right)$ with representatives of private enterprises of the SME sector, attended by eight respondents. Additionally, after conducting focused group interviews, telephone in-depth interviews $\left(\mathrm{TDI}^{8}\right)$ with FGI participants were conducted.

Figure 1 presents answers concerning the use of lower than maximum local tax rates and fees by the commune. In both provinces, answers confirming the use of the given instruments prevailed, while a higher percentage of such responses was observed in the Lublin province in comparison to the Mazovia province (the former $-70.59 \%$ of responses, the latter $-64.77 \%$ of responses).

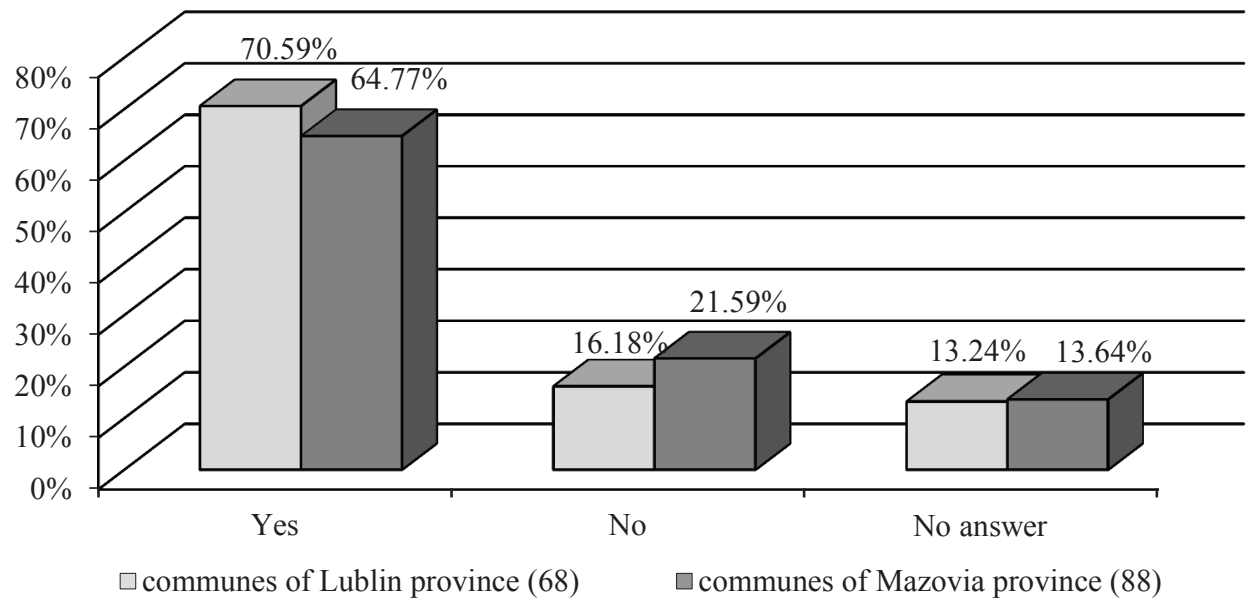

Fig. 1. The use of lower than maximum local tax rates and fees by communes

Source: own study.

Referring to the tax instrument which is the breaks and exemptions from local taxes and fees (excluding statutory breaks and exemptions) (Figure 2), more affirmative answers were also provided by communes from the Lublin province $(47.06 \%$ of responses); in addition, in the Mazovia province, the percentage of affirmative and negative answers was at the same level (43.18\% of responses).

Figure 3 presents the answers regarding the use, by the commune, as part of supporting enterprises, of the remission of arrears in local taxes and fees. Also in this prises".

${ }^{6}$ The study was financed from the WNEiZ grant No. 1228-E "Tax instruments to support enter-

${ }^{7}$ FGI - Focused Group Interview.

8 TDI - Telephone In-Depth Interview. 


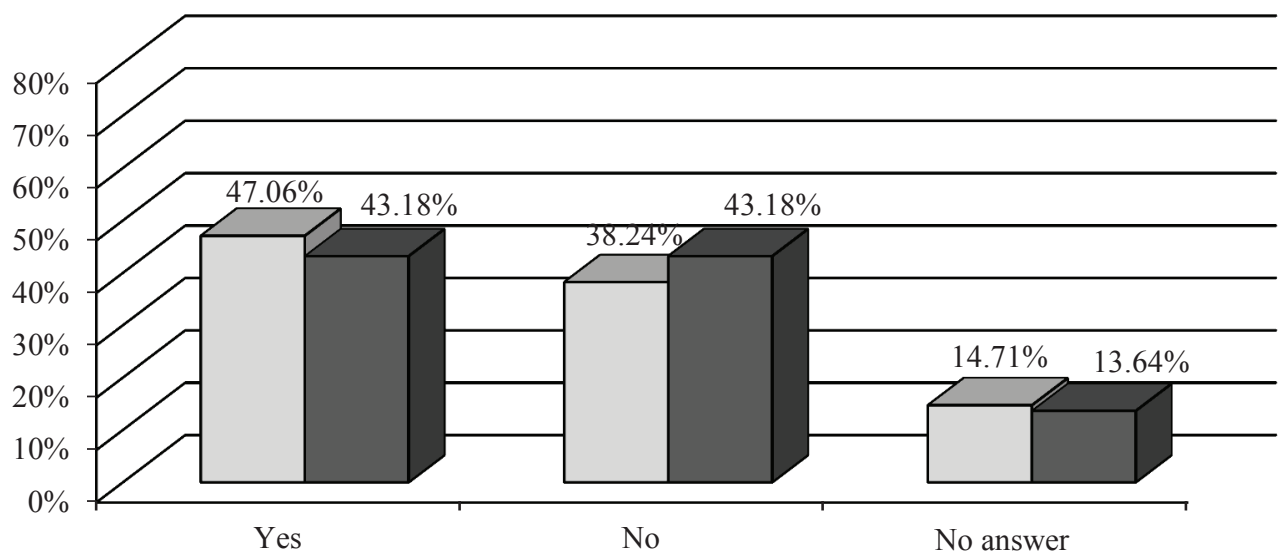

$\square$ communes of Lublin province (68)

$\square$ communes of Mazovia province (88)

Fig. 2. The use of breaks and exemptions from local taxes and fees by communes (excluding statutory breaks and exemptions)

Source: own study.

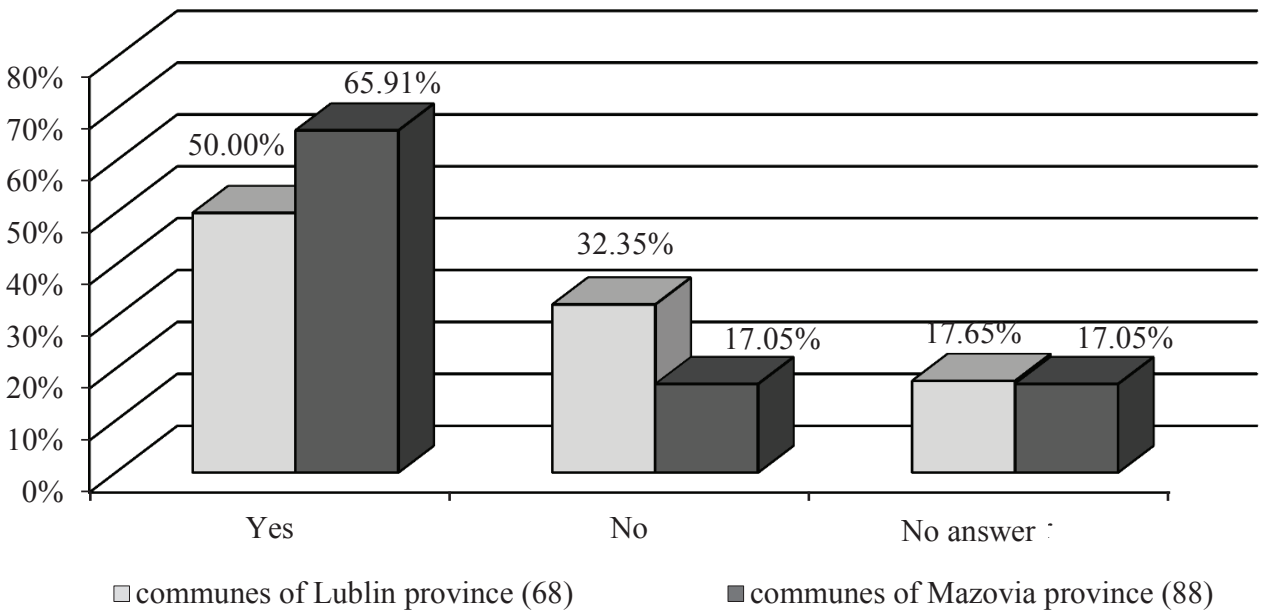

Fig. 3. The use of remissions of arrears in local taxes and fees by communes

Source: own study.

case, answers confirming the use of given instruments prevail in both provinces, with communes from the Mazovia province being more in favour of granting the given remissions (the Lublin province $-50 \%$ of responses, the Mazovia province $65.91 \%$ of responses). 
The last tool as part of tax instruments, which was subjected to assessment in terms of its use by the commune, was spreading the payment of local taxes and fees over instalments, or its deferment (Figure 4). Also in this situation, communes are more in favour of using the given instruments than not. In addition, a higher percentage of affirmative responses was recorded within communes from the Mazovia province compared to communes from the Lublin province (the Lublin

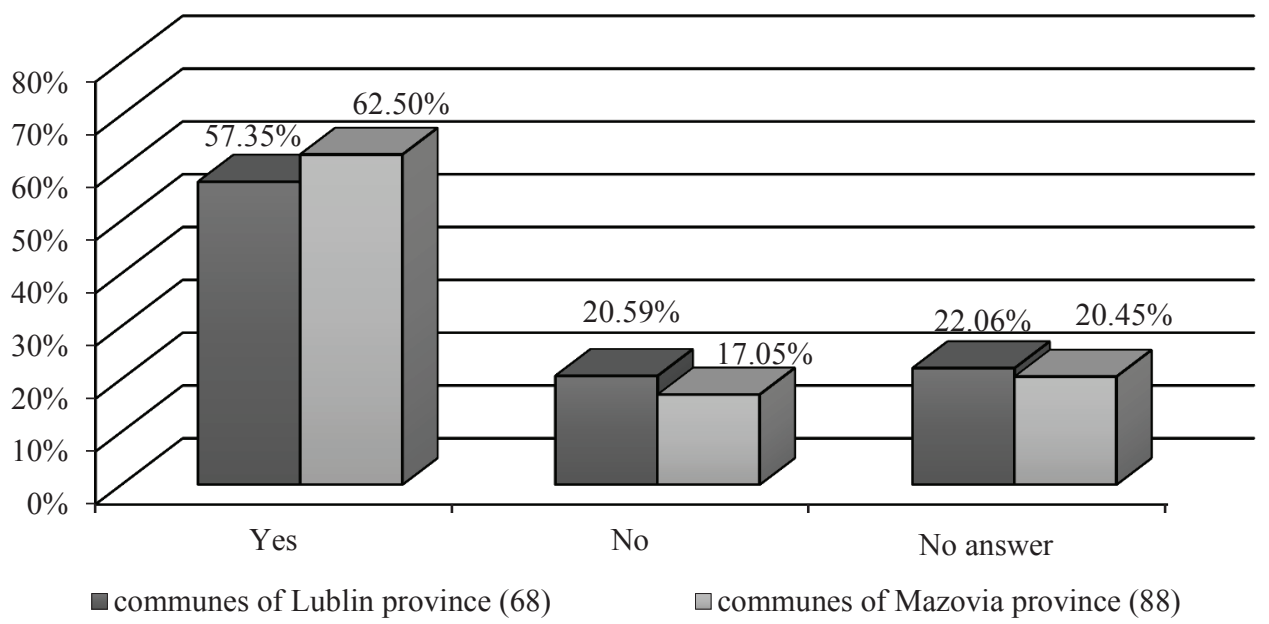

province $-57.35 \%$ of responses, the Mazovia province $-62.50 \%$ of responses).

Fig. 4. The use of spreading the payments of taxes and local fees over instalments and their deferments Source: own study.

Based on the focused group interview conducted among representatives of the SME sector, we find that, first of all, preferential tax rates are of paramount importance to enterprises, followed by breaks and exemptions (excluding statutory breaks and exemptions), spreading payments over instalments and their deferment, and finally the remission of arrears in local taxes and fees.

According to the respondents, spreading payments over instalments and the deferment in respect of local taxes and fees helps enterprises survive the worse financial period, avoid the consequences of failure to pay the tax, and makes it possible for the enterprise to maintain financial liquidity. In addition, they believe that tax breaks and exemptions used by communes in respect of local taxes and fees (excluding statutory breaks and exemptions) translate, in relation to enterprises, into lower operating costs of the enterprise, as a result of which they can afford to set competitive prices of goods, and the money saved on taxes can be reinvested in the company. In addition, they emphasize that the stability of the commune's policy regarding tax breaks and exemptions is also important for them, i.e. they prefer higher stable taxes than lower, but unstable ones. With a stable tax policy, they can 
calmly plan the company's expenses, which also helps them to create the company's strategy.

\section{Conclusion}

As a result of the conducted research it can be concluded that communes largely use tax instruments to support enterprises. Communes from the Lublin province, characterized by the lowest value of the synthetic entrepreneurship index, are more in favour of using instruments such as rates of local taxes and fees lower than the maximum, as well as breaks and exemptions from local taxes and fees (excluding statutory breaks and exemptions). On the other hand, communes from the Mazovia province, characterized by the highest value of the synthetic entrepreneurship index, prefer instruments such as the remission of arrears, spreading payments over instalments, and deferment of payments of local taxes and fees, i.e. instruments targeted at specific taxpayers.

Significantly, enterprises are also in favour of the commune using tax instruments due to the fact that this affects their financial situation. The most important for them are preferential tax rates, i.e. rates lower than the maximum rates set by the Minister of Finance, as well as breaks and exemptions (excluding statutory breaks and exemptions). Thus, it can be concluded that they value instruments that the commune addresses to all enterprises more than instruments which are associated only with selected enterprises.

Despite the positive tone of the use of tax instruments by the commune, it is worth emphasizing once again that easing tax burdens at a given time has a positive effect on enterprises, but at the same time it reduces the budgetary revenues necessary for the implementation of the commune's local authority tasks.

\section{Bibliography}

Cilak M., 2013, Instrumenty wspierania rozwoju gospodarczego stosowane przez samorzad terytorialny. Problematyka prawnofinansowa, Dom Organizatora.

Denek E., Rolewicz J., 1998, Budżetowe instrumenty samorzqdu terytorialnego $w$ polityce rozwoju przedsiębiorczości w matych miastach, [in:] J. Tarajkowski (ed.), Problemy polityki ekonomicznej: studia i szkice na jubileusz profesora Zdzisława Dabrowskiego, Wydawnictwo Akademii Ekonomicznej w Poznaniu, Poznań.

Kamińska A., 2011, Regionalne determinanty rozwoju małych i średnich przedsiębiorstw, Difin, Warszawa.

Kogut-Jaworska M., 2008, Instrumenty interwencjonizmu lokalnego w stymulowaniu rozwoju gospodarczego, CeDeWu, Warszawa.

Krajewski K., Śliwa J., 2004, Lokalna przedsiębiorczość w Polsce. Uwarunkowania rozwoju, Wydawnictwo Naukowe Wydziału Zarządzania Uniwersytetu Warszawskiego, Warszawa. 
Lachiewicz S., 2012, Rola matych i średnich przedsiębiorstw w rozwoju regionów, [in:] A. Adamik (ed.), Wspótpraca matych i średnich przedsiębiorstw $w$ regionie. Budowanie konkurencyjności firm i regionu, Difin, Warszawa.

Lisowska R., 2010, Kierowanie postaw przedsiębiorczych $w$ regionach zmarginalizowanych przez władze samorzqdowe, Zeszyty Naukowe nr 579, Ekonomiczne Problemy Usług nr 47, Szczecin, pp. 57-70.

Mate i średnie przedsiębiorstwa - kwestiq kluczowq dla zapewnienia wzrostu gospodarczego i zatrudnienia. Przeglad śródokresowy nowoczesnej polityki w zakresie MŚP, 2017, Komunikat Komisji dla Rady, Parlamentu Europejskiego, Europejskiego Komitetu Ekonomiczno-Społecznego i Komitetu Regionów, Komisja Wspólnot Europejskich, KOM(2007) 592 wersja ostateczna, Bruksela.

Raport o stanie sektora małych i średnich przedsiębiorstw, 2019, Polska Agencja Rozwoju Przedsiębiorczości, Warszawa.

Rolewicz J., 1996, Podatki jako instrument stymulowania rozwoju przedsiębiorczości w małych miastach, Gospodarka Narodowa, 6(72), pp. 15-19.

Skica T., Kiebała A., Wołowiec T., 2011, Stymulowanie lokalnej konkurencyjności gmin na przykładzie podatku od środków transportowych, Studia Regionalne i Lokalne, 2(44), pp. 118-139.

Słomińska B., 2007, Gmina w procesach stymulowania przedsiębiorczości, Samorząd Terytorialny, 3, pp. 19-33.

Uchwała nr XIII/125/15 Rady Gminy Bochnia z dnia 30 grudnia 2015 r. w sprawie zwolnień od podatku od nieruchomości w ramach pomocy de minimis, Dziennik Urzędowy Województwa Małopolskiego, Kraków, dnia 20 stycznia 2016 r., poz. 619.

Uchwała nr XXVII/172/16 Rady Gminy Gierałtowice z dnia 8 listopada 2016 r. w sprawie udzielania na obszarze Gminy Gierałtowice zwolnień od podatku od nieruchomości stanowiących regionalną pomoc inwestycyjną, Dziennik Urzędowy Województwa Śląskiego, Katowice, dnia 22 listopada 2016 r., poz. 5924.

Uchwała nr XXXIV/404/2014 Rady Miejskiej we Wrześni z dnia 16 września 2014 r. w sprawie zwolnień z podatku od nieruchomości udzielanych w ramach pomocy de minimis na terenie Gminy Września, Dziennik Urzędowy Województwa Wielkopolskiego, Poznań, dnia 18 września 2014 r., poz. 4885.

Uchwała nr XXXV/368/17 Rady Miejskiej Gminy Rawicz z dnia 14 lutego 2017 r. w sprawie zwolnień z podatku od nieruchomości gruntów na których rozpoczęto realizację nowej inwestycji - udzielanych w ramach pomocy de minimis, Dziennik Urzędowy Województwa Wielkopolskiego, Poznań, dnia 27 lutego 2017 r., Poz. 1549.

Ustawa z dnia 29 sierpnia 1997 r. - Ordynacja podatkowa, Dz. U. 2019, poz. 900.

Ustawa z dnia 6 marca 2018 r. - Prawo przedsiębiorców, Dz. U. 2018, poz. 646.

Wołowiec T., 2019, Preferencje w podatku od nieruchomości a reakcje podatników prowadzacych dziatalność gospodarcza, Samorząd Terytorialny, 4(340), pp. 25-43.

Wójtowicz K., 2013, Ulgi i zwolnienia w podatkach samorzqdowych jako instrument wsparcia rozwoju przedsiębiorczości w gminach (na przykładzie doświadczeń gmin miejskich województwa lubelskiego), Krytyka Prawa. Niezależne Studia nad Prawem, 5(1), pp. 411-439. 